\title{
International Journal of Technology Assessment in Health Care
}

\section{Instructions for Contributors}

The editors welcome submissions of articles that deal with the wide range of topics related to assessment for health care policy and practice, including issues of technology diffusion, economics, ethics, law, and social and cultural perspectives. All manuscripts are screened by the Editors and members of the Editorial Board. Those that pass proceed to an international review process, which usually is completed within 4 to 10 weeks. Accepted manuscripts will be published within 4 to 6 months. Articles must be in English. Spelling, capitalization, and punctuation should conform to the 15th Edition of The Chicago Manual of Style (University of Chicago Press). Articles and correspondence should be sent by email only to Marjukka Mäkelä at the following email address: marjukka.makela@thl.fi.

Preparation of Manuscript. The entire manuscript (in word format), including all notes and references, must be typed, doublespaced on $8 \frac{1}{1 / 2} \times 11$ inch or A4 paper, with at least 1-inch $(2.54 \mathrm{~cm})$ margins. Manuscript pages should be numbered consecutively. Manuscripts should be arranged as follows: 1) cover sheet with title and short title; 2) abstract and key words; 3) acknowledgments, including source of funding; 4) text; 5) references; 6) tables with titles; and 7) figures, with captions on a separate page. Manuscripts should typically have no more than 4,000 wordsincluding the abstract, which should not exceed 250 words. There should be no more than a total of four tables and illustrations together and no more than 25 references. Tables and illustrations exceeding these limits may be posted on the Journal's web site (www.journals.cambridge.org/thc) as supplementary materials. Supplementary figures and tables should be numbered separately from the figures and tables in the printed issue, beginning with Supplementary Figure 1 and Supplementary Table 1. Where relevant, all manuscripts should include one paragraph on the policy implications of the findings of the study. Acronyms should be clearly spelled out on first use. The use of product trade names should be avoided; generic names should be used except where discussion of proprietary brands is essential to the manuscript.

Cover Sheet And Cover LetTer. A cover letter, signed by all authors, must attest that 1) each named author contributed to both the conception/design and/or analysis/interpretation of the project and the writing of the paper; 2) each has approved the version being submitted; and 3 ) the content has not been published nor is being considered for publication elsewhere.

As relevant to the content of the paper, the letter should also attest to the fact that any research with human or animal subjects conforms to the legal and standards of the country in which it was performed. All authors must disclose any financial arrangements with companies whose products are discussed in the paper or their competitors; such information will not be revealed to reviewers but may be included in a suitable format in the final publication if the manuscript is accepted. The cover letter should also provide all authors' full names, professional degrees, and institutional mailing addresses.

The cover sheet should list the article's title, the name, complete mailing address, telephone and fax numbers, and e-mail address of the corresponding author, and a short title (50 characters or less) for the running head.
Abstract and Keywords. A 100- to 250-word abstract, submitted on a separate page, should summarize the objectives of the study or analysis, the article's major arguments and/or results, and its conclusions/recommendations. Abstracts must be submitted in four sections: Objectives; Methods; Results; and Conclusions, except where the subject and/or format of the article do not permit. Three to five key words, using terms from the Medical Subject Headings from Index Medicus, should follow the abstract.

REFERENCES AND Notes. Bibliographic citations in the text should be indicated by numbers in parentheses usually at the end of the sentence after the period. When authors are mentioned in the text, the citation number should immediately follow the name(s) as follows: In-text citations: "Jones and Smith (7) maintained that. .." The reference list must be in alphabetical order If a work has more than five authors, the first three authors should be listed, followed by et al. Abbreviate journal titles according to the listing in the current Index Medicus.

Book: 1. Jones AB, Smith JK. Computer diagnosis and results. New York: Penta Publishers; 1998.

Journal: 1. Jones AB, Smith JK. The relationship between health needs, the hospital, and the patient. J Chron Dis. 1995;32:310-312.

Article in edited work: 1 . Jones $\mathrm{AB}$, Smith JK. The diagnostic process. In: Brown R, Wilson T, eds. New technology and its medical consequences, vol. 1. New York: Apple Publishers; 1992:101-134.

In the reference list, do not include material that has been submitted for publication but has not yet been accepted. This material, with its date, should be noted in the text as "unpublished data" as follows:

Unpublished data: "Similar findings have been noted by L. W. Smith (unpublished data, 1998)."

The Journal does not accept footnotes or appendices.

Tables and Figures. Tables and figures should be numbered consecutively. All tables and figures must have a caption and must be cited in the text. Abbreviations in tables and figures should be avoided, except in the case of acronyms already used in the text. Table footnotes appear directly after the table; table references follow the footnotes. Figures must be submitted in Excel, PageMaker, or equivalent.

Permissions. Authors are responsible for obtaining written permission to publish material for which they do not own the copyright. Contributors will be asked to assign their copyrights to Cambridge University Press.

Copyediting And Proofreading. The publishers reserve the right to copyedit and proofread all accepted articles. Page proofs will be sent to the lead author for final review.

REPRINTS. Reprints may be purchased if ordered at proof stage. 


\section{International Journal of \\ TECHNOLOGY ASSESSMENT \\ IN HEALTH CARE}

Featured in this Issue

"Practical tools and methods for health technology assessment in Europe: Structures, methodologies,

and tools developed by the European network for Health Technology Assessment, EUnetHTA,"

by Finn Børlum Kristensen, Kristian Lampe, Deborah L. Chase, Sun Hae Lee-Robin, Claudia Wild,

Montse Moharra, Marcial Velasco Garrido, Camilla Palmhøj Nielsen, John-Arne Røttingen, Susanna Allgurin

Neikter, and Marie Louise Bistrup for the European network for Health Technology Assessment (EUnetHTA)

"The HTA Core Model: A novel method for producing and reporting health technology assessments,"

by Kristian Lampe, Marjukka Mäkelä, Marcial Velasco Garrido, Heidi Anttila, Ilona Autti-Rämö,

Nicholas J. Hicks, Björn Hofmann, Juha Koivisto, Regina Kunz, Pia Kärki, Antti Malmivaara,

Kersti Meiesaar, Päivi Reiman-Möttönen, Inger Norderhaug, Iris Pasternack,

Alberto Ruano-Ravina, Pirjo Räsänen, Ulla Saalasti-Koskinen, Samuli I. Saarni,

Laura Walin, and Finn Børlum Kristensen for the European network for

Health Technology Assessment (EUnetHTA)

"Testing the HTA Core Model: Experiences from two pilot projects," by Iris Pasternack, Heidi Anttila,

Marjukka Mäkelä, Tuija Ikonen, Pirjo Räsänen, Kristian Lampe, Hans van Brabandt, Irina Cleemput,

Chris de Laet, Marco Marchetti, Pietro Refolo, Dario Sacchini, Regina Kunz, Alain Nordmann,

Dagmar Lühmann, and Bo Freyschuss for the European network for Health Technology

Assessment (EUnetHTA)

"The adaptation of health technology assessment reports: Identification of the need for, and development of, a toolkit to aid the process," by Sheila Turner, Deborah L. Chase, Ruairidh Milne, Andrew Cook,

Nicholas J. Hicks, Claire Rosten, Liz Payne, Suzanne Coles, and Eleanor Bell for the

European network for Health Technology Assessment (EUnetHTA)

"The health technology assessment adaptation toolkit: Description and use," by Sheila Turner, Deborah L. Chase,

Ruairidh Milne, Andrew Cook, Nicholas J. Hicks, Claire Rosten, Liz Payne, Suzanne Coles, and Eleanor Bell for the European network for Health Technology Assessment

(EUnetHTA)

"Enhancing understanding: The development of a glossary of health technology assessment adaptation terms,"

by Claire Rosten, Deborah L. Chase, Nicholas J. Hicks, and Ruairidh Milne for the European network for Health Technology Assessment (EUnetHTA)

"Information service on new and emerging health technologies: Identification and prioritization processes for a European Union-wide newsletter,” by Claudia Wild, Sue Simpson, Karla Douw,

Sabine Geiger-Gritsch, Stefan Mathis, and Thomas Langer

"A common policy framework for evidence generation on promising health technologies,"

by Cédric Carbonneil, Fabienne Quentin, and Sun Hae Lee-Robin for the European network for Health Technology Assessment (EUnetHTA)

"Web-based toolkit to facilitate European collaboration on evidence generation on promising health technologies,” by Fabienne Quentin, Cédric Carbonneil, Céline Moty-Monnereau, Elena Berti,

Wim Goettsch, and Sun Hae Lee-Robin for the European network for Health Technology Assessment (EUnetHTA)

"Systems to support health technology assessment (HTA) in Member States of the European Union with

limited institutionalization of HTA," by Montse Moharra, Mireia Espallargues, Nadine Kubesch,

Maria-Dolors Estrada, Antoni Parada, Hindrik Vondeling, Alessandra Lo Scalzo, Stelios Cristofides,

Eva Turk, and Martin Raab on behalf of Work Package 8 of the European network for Health Technology Assessment (EUnetHTA) project

Cambridge Journals Online

For further information about this journal please

go to the journal website at:

journals.cambridge.org/thc
Mixed Sources

Product group from well-managed

forests, controlled sources
recycled wood or fiber

recycled wood or fiber
www.fsc.org Cert no. SW-COC-002828

www.fsc.org Cert no. SW-COC-00282
๑) 1996 Forest Stewardship Council
Co.s CAMBVRSITY PRESS 